\title{
TRANSITIONAL ARRANGEMENTS IN THE ENLARGED EUROPEAN UNION: HOW FREE IS THE FREE MOVEMENT OF WORKERS?
}

\begin{abstract}
Iris Goldner Lang*
Summary: This paper questions the necessity and legitimacy of transitional arrangements in the field of free movement of workers imposed on the ten Central and Eastern European states which joined the EU in 2004 and 2007. It addresses the issue of free movement of labour in the enlarged Union in the context of the policy reasoning behind such transitional arrangements. Present transitional periods are contrasted with other solutions (such as allowing immigration quotas), which would have been politically fairer and psychologically wiser in confronting the arguments on the divide between 'first class' and 'second class' EU membership. The paper suggests that the results of the most recent studies, showing that the fears of the old Member States were mostly unfounded and that economic and social benefits result from the free movement of workers in the EU, should be taken into consideration for the next enlargement.
\end{abstract}

\section{Introduction}

On 1 May 2004 eight Central and Eastern European states ${ }^{1}$ became EU Member States and, as such, have to abide by the acquis which applies to them, as equal partners with the old Member States. They were joined by Bulgaria and Romania on 1 January 2007. However, the process of the full integration of these states into the Union and the acquisition of equal rights of their nationals identical to those of the nationals of the old Member States were not fully achieved on the respective dates. In certain areas, such as free movement of workers, the ten new Member States were or still are subject to special transitional arrangements. In the transitional period, the old Member States, if they so choose, can restrict access to their labour markets for nationals from the new Member States by applying to them their domestic laws and, thus, treat them less favourably than the nationals of the old Member States.

\footnotetext{
* Assistant Professor, Department of European Public Law, Faculty of Law, University of Zagreb.

1 The Czech Republic, Estonia, Hungary, Latvia, Lithuania, Poland, Slovakia, and Slovenia. Apart from these eight Central and Eastern European states, Cyprus and Malta also joined the EU on the same date.
} 
In this paper, transitional periods in the field of free movement of workers (and service providers in the case of Austria and Germany) are explored in the context of the policy reasoning behind such arrangements. The very legitimacy of such transitional periods is considered. The first part of the paper provides a brief account of the developments in the field during the accession negotiations and offers a critical overview of the functioning of transitional periods. The second part of the paper questions the necessity and legitimacy of transitional periods and addresses the issue of free movement of labour in the enlarged Union as a political, economic and social question. It analyses the effects of transitional periods so far and contrasts transitional arrangements with other solutions (such as allowing immigration quotas) which could have been applied instead.

\section{Functioning of Transitional Arrangements}

Before approaching the issue of the legitimacy of transitional periods in the field of free movement of workers, the developments leading to the present state of affairs should be considered. Free movement of workers was part of the accession negotiations with the ten Central and Eastern European states under Chapter 2, dealing with freedom of movement for persons. ${ }^{2}$ The most problematic issue of access to the labour market of the old Member States to nationals coming from the acceding states was first elaborated in the European Commission's Information Note 'The Free Movement of Workers in the Context of Enlargement'. ${ }^{3}$ In the executive summary, the Commission referred to the EU Common Position on Chapter 2 of May 2000, which underlined 'the political and practical importance of this area of the acquis' and noted 'that there are sensitivities over the issue of mobility of workers' which 'will have to be taken into account at a later stage of the negotiations'. ${ }^{4}$

\footnotetext{
2 For the purpose of the accession negotiations, the acquis communautaire was divided into 31 chapters: 1)Free Movement of Goods; 2) Freedom of Movement for Persons; 3) Freedom to Provide Services; 4) Free Movement of Capital; 5) Company Law; 6) Competition Policy; 7) Agriculture; 8) Fisheries; 9) Transport Policy; 10) Taxation; 11) Economic and Monetary Union; 12) Statistics; 13) Social Policy and Employment; 14) Energy; 15) Industrial Policy; 16) Small and Medium-Sized Undertakings; 17) Science and Research; 18) Education and Training; 19) Telecommunications and Information Technologies; 20) Culture and Audiovisual Policy; 21) Regional Policy and Coordination of Structural Instruments; 22) Environment; 23) Consumer and Health Protection; 24) Cooperation in the Fields of Justice and Home Affairs; 25) Customs Union; 26) External Relations; 27) Common Foreign and Security Policy; 28) Financial Control; 29) Financial and Budgetary Provisions; 30) Institutions; 31) Other.

3 Commission (EC), 'Information Note on the Free Movement of Workers in the Context of Enlargement' of 6 March 2001.

4 Commission (EC) (n 3) 2.
} 
The Information Note presented five options regarding the model for the movement of workers from the new to the old Member States ranging from complete application of the acquis, through various transitional arrangements to the complete non-application of the acquis for a specific period. ${ }^{5}$ Based on the Information Note and the reactions to it, the Commission made its Draft Common Position (DCP) for each of the ten states whose negotiations on Chapter 2 had been opened. The DCPs resembled option 3 from the Information Note ('Flexible System of Transitional Arrangements') and provided for a general transitional period of five years with an extension for another two years $(5+2)$ in the event of serious disturbances in the labour market of the relevant old Member State.

Based on the DCPs, the Council reached the EU Common Position in May 2001. In comparison to the DCPs, the EU Common Position accepted a somewhat more flexible and less restrictive model of $2+3+2$ years, which was later followed with the closure of accession negotiations on Chapter $2^{6}$ and the conclusion of the Accession Treaty. The first three Central and Eastern European states to close negotiations on Chapter 2 were Hungary, Latvia and Slovakia in June 2001. ${ }^{7}$ The Czech Republic closed negotiations on Chapter 2 in October 2001, Lithuania in November 2001, Poland and Slovenia in December 2001, and Estonia in March 2002. The two Central and Eastern European states that joined the EU only in 2007 lagged behind the first eight. Thus, Bulgaria closed negotiations on Chapter 2 in June 2002 and Romania only in December 2003. The eight Central and Eastern European states that joined the Union in 2004 accepted the EU Common Position, with some slight modifications.

The transitional arrangements on the free movement of persons, as annexed to the two Acts of Accession, actually only refer to the movement of workers (and service providers, as regards certain sectors of service, in the case of Germany and Austria) from the new to the old Member States, and vice versa from the old to the new Member States, as well as from one to another new Member State. Other groups of nationals of the new Member States enjoy complete freedom of movement from the date of accession (eg persons who are not economically active, such as students or retired persons; posted workers, with the exception of Germany and

\footnotetext{
5 Commission (EC) (n 3) 17.

6 For the Results of accession negotiations on all chapters, see 'Report on the Results of the Negotiations on the Accession of Cyprus, Malta, Hungary, Poland, the Slovak Republic, Latvia, Estonia, Lithuania, the Czech Republic and Slovenia to the European Union' <http://ec.europa.eu/enlargement/archives/pdf/enlargement_process/future_prospects/ negotiations/eu10_bulgaria_romania/negotiations_report_to_ep_en.pdf > accessed 10 October 2007 and the 'Report on the Results of the Negotiations on the Accession of Bulgaria and Romania to the European Union' <http://ec.europa.eu/enlargement/archives/pdf/result_of_neg_final_council_version_st05859_0405_en.pdf > accessed 10 October 2007.

7 Cyprus and Malta also closed Chapter 2 in June 2001.
} 
Austria; and self-employed persons from a new Member State wishing to establish themselves in an old Member State).

As regards the movement of workers, it is only the access to the labour market that is restricted by transitional measures, and not other rights linked to the free movement of workers. Transitional arrangements concerning the movement of workers derogate from Article 39 EC, Articles 1 to 6 of Regulation 1612/68 and certain provisions of Directive $68 / 360^{9}$ (in the case of the Act of Accession of Cyprus, the Czech Republic, Estonia, Latvia, Lithuania, Hungary, Malta, Poland, Slovenia and Slovakia), and Directive 2004/38/EC ${ }^{10}$ which replaced Directive 68/360 (in the case of the Act of Accession of Bulgaria and Romania), insofar as some of their provisions may not be dissociated from those of Regulation $1612 / 68$. As regards service providers, the arrangements derogate from Article 49(1) EC and Article 1 of Directive 96/71.11

The arrangements started with an initial two-year transitional period starting from the date of accession. In this period, the acquis relating to the access of workers from the new Member States to the labour market of the old Member States is suspended and Member States apply their national measures or those resulting from bilateral agreements with the acceding Member States. ${ }^{12}$ Nationals from the acceding Member States already legally working in one of the old Member States at the date of accession and admitted to the labour market of that Member State for an uninterrupted period of 12 months or longer have access to the labour market of that Member State but not of other Member States applying national measures. The same applies to nationals of acceding Member States admitted to the labour market of one of the old Member States following accession for an uninterrupted period of 12 months or longer. ${ }^{13}$

8 Council Regulation 1612/68/EEC of 15 October 1968 on freedom of movement for workers within the Community [1968] OJ Spec Ed (III) 475.

9 Council Directive 68/360/EEC of 15 October 1968 on the abolition of restrictions on movement and residence within the Community for workers of Member States and their families, [1968] OJ Spec Ed (III) 485.

10 Directive 2004/38/EC of the European Parliament and of the Council of 29 April 2004 on the right of citizens of the Union and their family members to move and reside freely within the territory of the Member States amending Regulation (EEC) No 1612/68 and repealing Directives 64/221/EEC, 68/360/EEC, 72/194/EEC, 73/148/EEC, 75/34/EEC, 75/35/EEC,90/364/EEC, 90/365/EEC and 93/96/EEC [2004] OJ L158/77.

11 European Parliament and Council Directive 96/71 of 16 December 1996 concerning the posting of workers in the framework of the provisions of services [1996] OJ L18/1.

12 For an overview of national measures and bilateral agreements of the old Member States with regard to the admission of third country nationals in 2000, see Table 1 . For an overview of transitional measures concerning the free movement of workers from the new to the old Member States after 1 May 2004, see Table 2.

13 See Annex XII to the Act of Accession regulating transitional measures between Poland and other Member States - Part 2 'Freedom of Movement for Persons' para 2; Annex VI to the Act of Accession regulating transitional measures between Bulgaria and other Member States - Part 2 'Freedom of Movement for Persons' para 2. 
Nationals of acceding Member States admitted to the labour market of the old Member States for a period shorter than 12 months do not enjoy these rights. However, it should be pointed out that the dividing line between those admitted for more or less than 12 months does not have any influence on their right to equal treatment as regards working conditions, remuneration, dismissal and other conditions, since these rights are guaranteed by Article 7 of Regulation 1612/68 which is not subject to any transitional derogations. All those legally employed, no matter whether they are nationals of old or new Member States, are to be treated equally in respect of their work.

For the eight Central and Eastern European states that joined the EU on 1 May 2004, the initial two-year transitional period ended on 30 April 2006. For Bulgaria and Romania, which acceded on 1 January 2007, this period will be over on 31 December 2008. The experiences gained by the application of the first two-year transitional period will be analysed further in the text. At this point, it should be stated that at the point of the 2004 enlargement, twelve out of fifteen old Member States decided to use the right to transitional arrangements with regard to access to their labour market for workers coming from new Member States. Only Ireland, Sweden and the United Kingdom decided to liberalise access to their labour markets under their national law to nationals coming from the new Member States. Ireland and Sweden did not apply any restrictions whatsoever, and thus enabled nationals of the new Member States to become employed on their territories under the same conditions as nationals coming from the old Member States. The United Kingdom adopted a mandatory Worker's Registration Scheme in order to track any changes on the UK labour market. The remaining old Member States maintained their work permit systems, sometimes combining them with a quota system (for a more detailed description of national transitional measures of the old fifteen Member States after the 2004 enlargement, see Table 2).

On the other hand, at the point of the 2007 accession of Bulgaria and Romania, out of twenty-five old Member States, ten (the Czech Republic, Cyprus, Estonia, Finland, Latvia, Lithuania, Poland, Slovakia, Sweden) decided to liberalise the access of Bulgarian and Romanian workers to their labour markets under national law. In Cyprus, Finland and Slovenia, employment must subsequently be registered for monitoring purposes. The remaining fifteen Member States maintained their work permit systems, sometimes modifying or simplifying the procedures. (For a detailed description of the national transitional periods of the old twentyfive Member States for Bulgarian and Romanian nationals after the 2007 enlargement, see Table 3.)

The initial two-year transitional period can be prolonged by another three years $(2+3)$ only for those old Member States that decide to maintain national restrictions for certain new Member States of their choice. 
Such a decision is preceded by the report the European Commission has to submit to the Council before the expiry of the initial two-year transitional period. ${ }^{14}$ For the states that acceded to the Union in May 2004, the Commission submitted to the Council on 8 February 2006 the Report on the Functioning of the Transitional Arrangements set out in the 2003 Accession Treaty (period 1 May 2004 - 30 April 2006). ${ }^{15}$ In the Report, the Commission used statistical analysis (for a detailed overview of these results, see Tables 5, 6 and 7) in order to show the old Member States the benefits of lifting transitional restrictions upon the expiry of the initial two-year period. At the same time, the Commission reminded the old Member States that freedom of movement of workers is one of the basic freedoms under the EC Treaty and that the actual benefits of enlargement can only be seen with the complete application of Community law.

Following the Council's review of the Commission's report, the old Member States had to notify the Commission by 30 April 2006 if they wished to continue the restrictions for one or more acceding Member States. In the cases of Bulgaria and Romania, the initial two-year period will expire on 31 December 2008, by which date the old Member States will have to notify the Commission if they wish to continue the restrictions for Bulgarian and Romanian nationals. Without such a notification, the acquis applies automatically. ${ }^{16}$ This means that following the expiry of the initial two-year period, old Member States may have a differential treatment for different new Member States, by maintaining transitional arrangements for one Member State and abandoning the restriction for another.

At the moment of writing this text, nine out of fifteen old Member States have opened their labour markets completely for workers from the eight Central and Eastern European states that acceded to the Union in

14 This obligation is based on the Annex to the Act of Accession regulating transitional measures in the field of free movement of workers, para 3.

15 Report on the Functioning of the Transitional Arrangements set out in the 2003 Accession Treaty (period 1 May 2004 - 30 April 2006), COM(2006) 48 final, 8 February 2006.

The Commission previously convened a meeting of a High Level Group on Free Movement of Persons. The group met on 16 September 2005 to discuss the functioning of transitional arrangements. In addition to Member States' representatives, it included representatives of European and national social partners. At the meeting, a number of the old Member States informed the Commission that they had commenced internal consultations to determine their position in the second phase. Some Member States expressed their intention to lift transitional restrictions, while others decided to maintain them. The majority of social partners were in favour of lifting the restrictions. It was acknowledged that the restrictions may have encouraged nationals coming from new Member States to look for other ways of performing economic activity in the old Member States, which led to an exceptionally high influx of posted workers and workers who claimed to be self-employed (see paras 8-9 of the Report).

16 See Annex XII (n 13) para 3; Annex VI (n 13) para 3. 
2004. Ireland, Sweden and the United Kingdom had already opened their labour markets during the first phase. They were followed by Spain, Finland, Greece and Portugal as of 1 May 2006, and by Italy as of 27 July 2006. The Netherlands lifted all restrictions on 1 May 2007. The United Kingdom has maintained its mandatory Worker's Registration Scheme, and in Finland employment must subsequently be registered for monitoring purposes. Belgium, Denmark, France and Luxembourg have maintained restrictions but have simplified their existing national access regimes or procedures. As expected, Germany and Austria have notified the Commission that they will maintain national restrictions for the second three-year period, including in relation to the provision of services.

After five years, old Member States may choose to extend the transitional period for another two years in the event of serious disturbances in their labour markets or if there is a threat thereof $(2+3+2)$, thus reaching the maxim seven-year transitional period. In this case, Member States must, again, notify the Commission. Without such a notification, the restrictions are automatically lifted and the acquis starts to apply. ${ }^{17}$ Significantly, in both the second $(+3)$ and the third (+2) part of the transitional period, it is up to the Member States to decide whether they want to prolong the restrictions.

The old Member States that decide to lift their national restrictions before the expiry of the seven-year period are entitled to invoke a safeguard clause until the end of the seventh year if they undergo or if they foresee disturbances in their labour market. In such a case they have to inform the Commission and other Member States thereof and request the Commission to suspend, wholly or partially, the application of Articles 1 to 6 of Regulation 1612/68. In urgent and exceptional cases, a Member State may itself suspend the application of the relevant Article of Regulation 1612/68 and inform the Commission ex post. ${ }^{18}$

The transitional measures differentiate between two categories of family members ${ }^{19}$ of workers from the new Member States - those legally residing with the worker (admitted for a period of more than 12 months) in the territory of an old Member State already at the date of accession, and those legally residing with the worker in the territory of an old Member State from a date later than the date of accession. The first category have immediate access to the labour market of that Member State upon accession, while the second category have such access only 'once they have been resident in the Member State concerned for at least 18 months

\footnotetext{
17 See Annex XII (n 13) para 5; Annex VI (n 13) para 5.

18 See Annex XII (n 13) para 7; Annex VI (n 13) para 7.

19 The list of family members is identical to that referred to in Article 10(1)(a) of Regulation $1612 / 68$.
} 
or from the third year following the date of accession, whichever is earlier'. ${ }^{20}$ The position of the second category of family members could be interpreted as a case of discrimination, whereas a worker who has been admitted to the labour market of an old Member State after accession, for an uninterrupted period of 12 months or longer, cannot immediately claim the same rights for his/her family members. It is difficult to find arguments for such a restriction, especially in view of the fact that the worker's residence is of more than just a temporary character and he might have problems in supporting his family members if they are not allowed to work. Such a view is supported by the fact that a worker who is admitted to the labour market of an old Member State after accession for a minimum period of 12 months enjoys the same rights as one who had been admitted for such a period before accession, so it would seem reasonable that the rights of family members of these two categories of workers should follow this analogy. Additionally, the opening provisions of the transitional measures on free movement of persons do not mention any derogation with regard to the family reunification provisions contained in Regulation 1612/68 (Art 10-12) or the relevant provisions on family reunification of Directive 2004/38 on the right of citizens of the Union and their family members to move and reside within the territory of the Member States, ${ }^{21}$ but this measure seems to extend the derogations to these provisions on family reunification.

Transitional measures on free movement of workers establish two additional principles applying to the whole seven-year period. First, a standstill clause ${ }^{22}$ prohibits any worsening of access to the labour market of the old Member State to nationals of the new Member States that existed at the time of signing the Accession Treaty. On the contrary, in the first two years, old Member States may, under national law, introduce 'greater freedom of movement than that existing at the date of accession, including full labour market access'. ${ }^{23}$ Upon the expiry of the two-year period and before the end of the seventh year, old Member States may at any point decide to abandon the restrictions and apply the acquis. ${ }^{24}$ This means that status quo is the minimum requirement and any measure more favourable to the nationals of the acceding Member States is welcome.

Second, the principle of Community preference will be employed for the whole transitional period. It anticipates that nationals of new Mem-

20 See Annex XII (n 13) para 8; Annex VI (n 13) para 8.

21 Arts 10 and 11 of Regulation 1612/68 have been repealed by Directive 2004/38, which now covers family reunification issues.

22 See Annex XII (n 13) paras 13-14; Annex VI (n 13) paras 13-14.

23 See Annex XII (n 13) para 12; Annex VI (n 13) para 12.

24 See Annex XII (n 13) para 12; Annex VI (n 13) para 12. 
ber States have priority in access to the labour market of the old Member States over third country nationals and, reciprocally, that nationals from the old Member States have priority in access to the labour market of the new Member States over any third country nationals. This means that, in the transitional regime, workers who are nationals of one of the old Member States (and European Economic Area nationals) have top priority for any employment in the Union, followed by nationals from new Member States that are subject to transitional regimes. Only if there is no one available for a certain vacancy from either of these two groups will the post be open for third country nationals. However, Ziegler warns that the implementation of the principle of Community preference depends on 'the information efforts of national employment services, supported by EURES, ${ }^{25}$ to supply the relevant information to the new Member States'. ${ }^{26}$ Unless a national of a new Member State is aware of a vacancy in the old Member State, he will not be able to apply for the post.

Germany and Austria, as the two Member States most likely to absorb migrants from new Member States, were successful in arguing that without an extension of the transitional regime to the provision of services in certain sectors, the restrictions to the free movement of workers could easily be circumvented. ${ }^{27}$ They managed to gain the right to impose restrictions on the provision of services to the temporary movement of workers from companies established in the acceding Member States, as long as they apply transitional measures to the free movement of workers. ${ }^{28}$ The restrictive measures can be applied if there are serious disturbances in specific sensitive service sectors or if there is a threat thereof, ${ }^{29}$ but the decision whether or not to apply such measures is completely up to Germany and Austria, while their only obligation is to notify the Commission.

All restrictive measures concerning the movement of workers and the provision of services can be applied reciprocally. This means that the

25 European Employment Services (EURES) is a cooperation network designed to facilitate the free movement of workers within the European Economic Area (Switzerland is also involved). Partners in the network include public employment services, and trade union and employers' organisations. The network is coordinated by the European Commission.

${ }^{26}$ G Ziegler, 'The Accession Negotiations on Free Movement of Workers' in A Ott and K Inglis (eds), Handbook on European Enlargement (CUP, Cambridge 2002) 137.

27 G Ziegler (n 26) 139.

28 See Annex XII (n 13) para 13.

29 Sectors covered by such derogations in Germany are: construction, including related branches; industrial cleaning; activities of interior decorators. Austria is entitled to keep the restriction in the following sectors: horticultural service activities; cutting, shaping and finishing stone; manufacture of metal structures and parts of structures; construction, including related branches; security activities; industrial cleaning; home nursing; social work and activities without accommodation. 
acceding states are entitled to restrict access to their labour market to nationals of the old Member States which keep in force equivalent measures with regard to nationals of the acceding Member State(s) in question. ${ }^{30}$ Even though the practical value of reciprocal provisions is of little importance since there is not much likelihood of any significant number of migrants moving from the old to the new Member States, the importance of these provisions should not be underestimated, since it must have been politically easier for the acceding Member States to accept transitional regimes that can be applied reciprocally. Out of eight Central and Eastern European states that acceded to the Union in 2004, three (Hungary, Poland and Slovenia) decided to apply reciprocity to the fifteen old Member States during the initial two-year period. At the time of writing this text, only Hungary still applies reciprocal measures. Slovenia ceased to apply reciprocity on 25 May 2006 and Poland on 17 January 2007. None of these eight Central and Eastern European states have applied for permission to restrict access to workers from the other seven new Member States. On the other hand, Bulgaria and Romania that joined the Union in 2007 have decided not to restrict access to their labour markets for nationals from the fifteen (out of twenty-five) other Member States which apply restrictions for Bulgarian and Romanian workers.

The safeguard clause, suspending access to the labour market if there are current or foreseen disturbances, can also be applied by the acceding Member States in a highly extensive manner. An acceding Member States is entitled to resort to the safeguard procedure in respect of any other acceding Member State ${ }^{31}$ as long as an old Member State is still applying restrictive measures to nationals of any acceding Member State. Consequently, after an initial two-year transitional period, a situation could arise where, for example, Hungary is using a safeguard clause in respect of Slovakia, even if no old Member State is applying restrictive measures against Slovakia, but is doing so towards another acceding Member State. So far, none of the eight Central and Eastern European States that acceded to the Union in 2004 has applied the safeguard clause. Consequently, Community law on free movement of workers fully applies among these eight Central and Eastern European states.

30 See Annex XII (n 13) paras 10 and 13; Annex VI (n 13) paras 10 and 13.

31 Except for Cyprus and Malta, the only two acceding states not undergoing a transitional regime for the free movement of persons. 


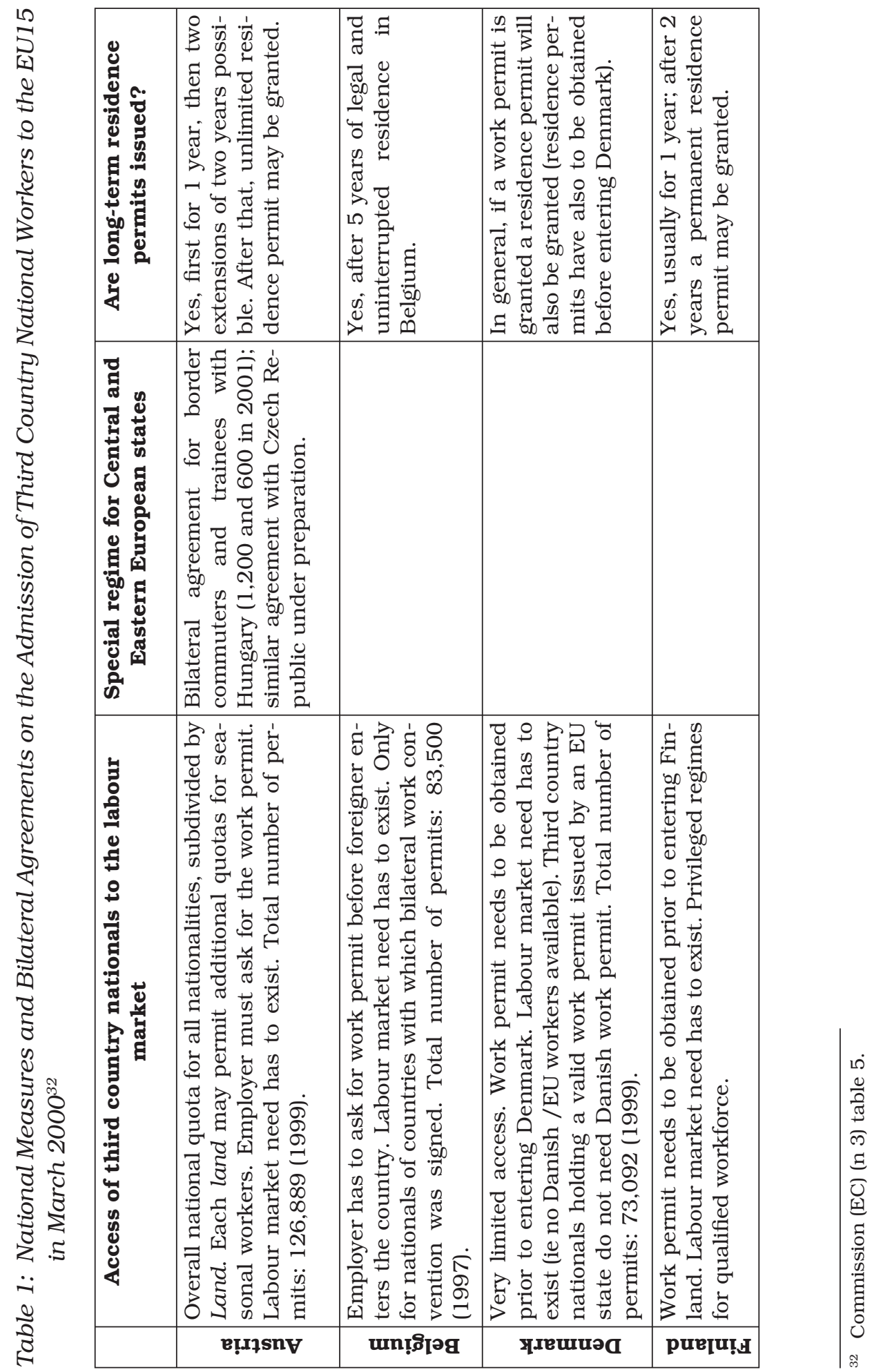




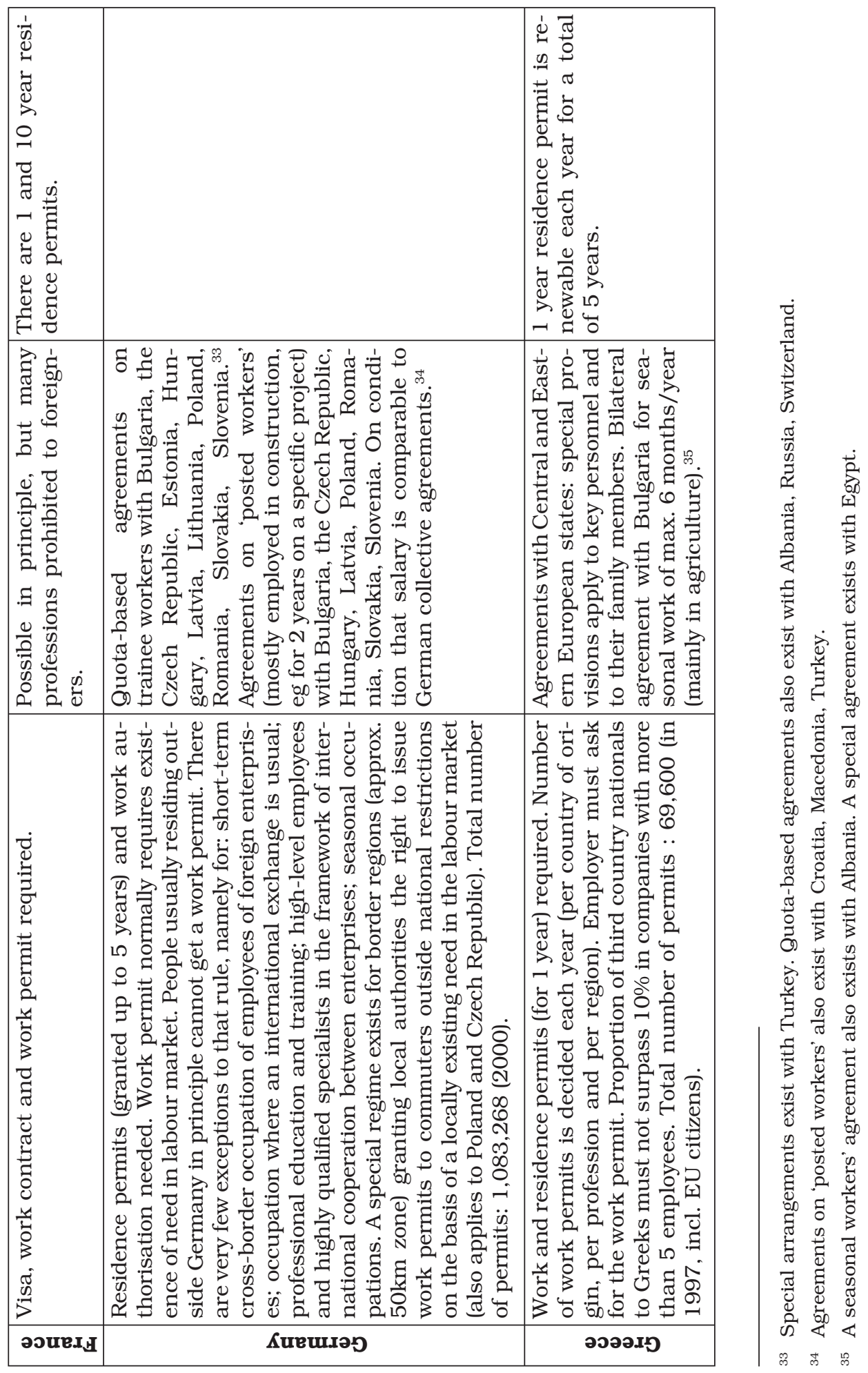




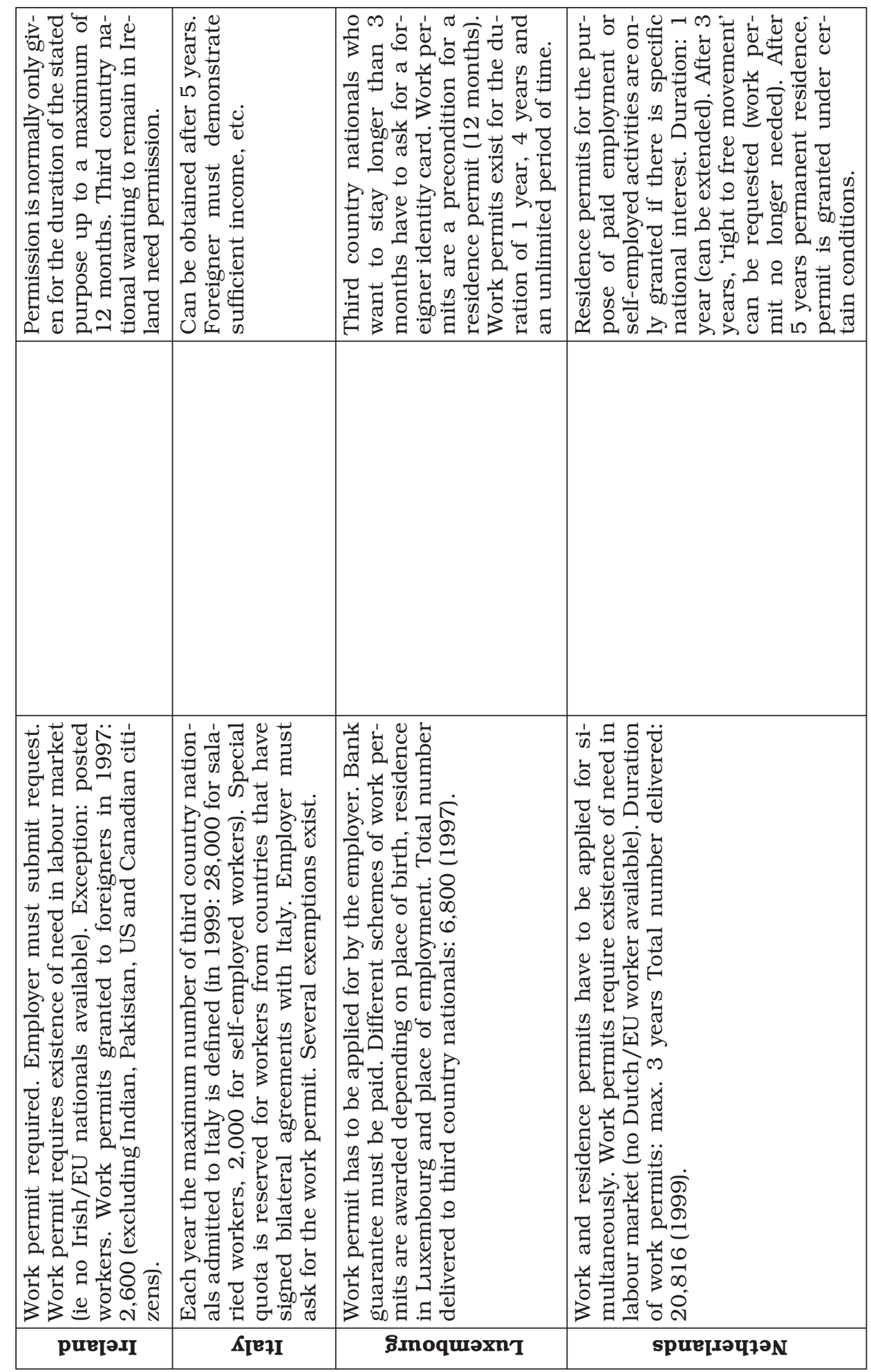




\begin{tabular}{|c|c|c|c|}
\hline 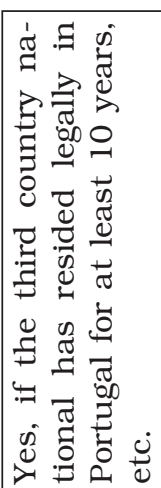 & 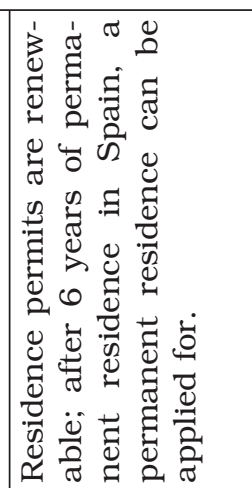 & 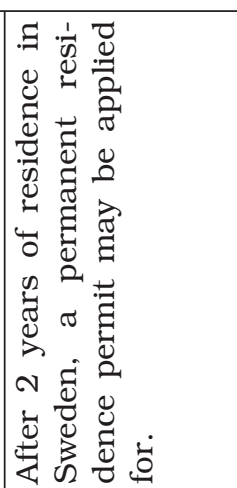 & 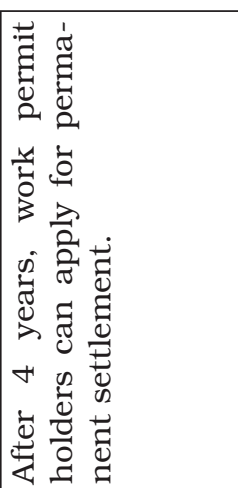 \\
\hline & & 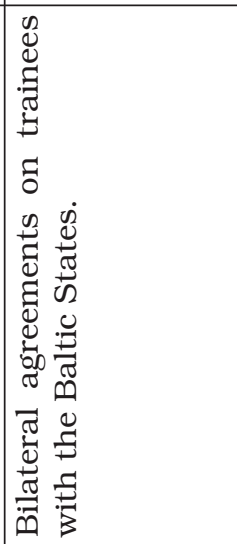 & 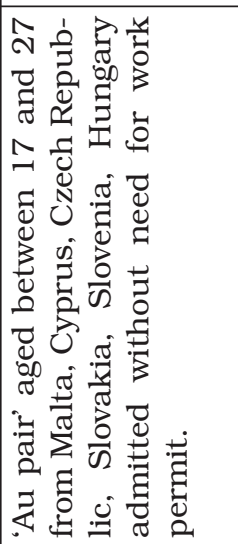 \\
\hline 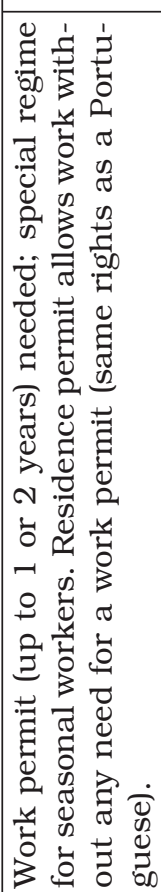 & 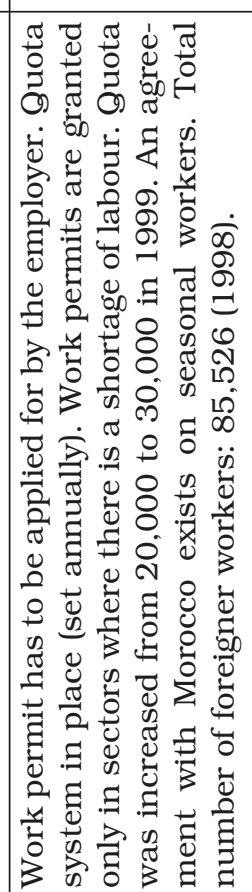 & 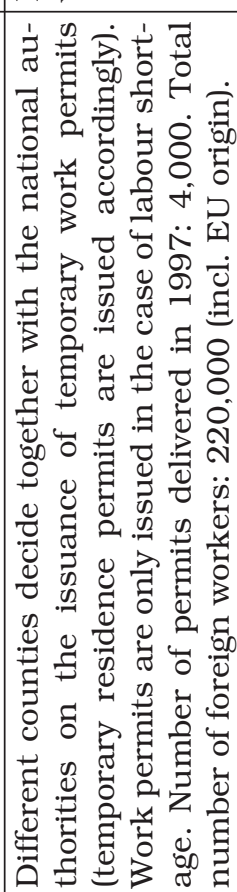 & 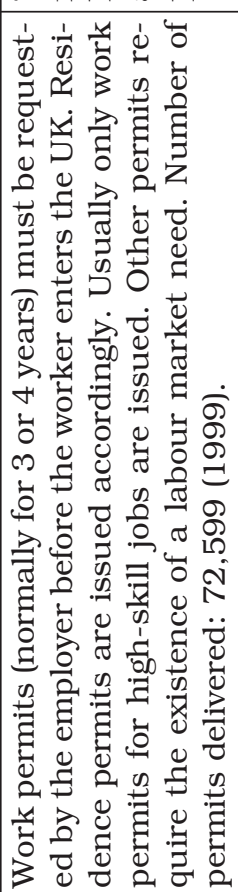 \\
\hline [eฮిnๆIod & u!̣eds & uəрәмS & yn \\
\hline
\end{tabular}


Table 2: Free movement of workers from the new to the old Member States on 1 May 2004: an overview of transitional measures ${ }^{36}$

\begin{tabular}{|c|c|}
\hline & $\begin{array}{l}\text { National restrictions apply: } \\
\text { New EU citizens wishing to work in Austria still need a restricted work per- } \\
\text { mit, for which their employer must apply. Once a worker has been employed } \\
\text { legally for one year, his freedom to move within the labour market will be } \\
\text { confirmed by the Labour Market Service. Family members will receive this } \\
\text { right only after } 18 \text { months. The right to such freedom of movement will be } \\
\text { relinquished if the worker leaves the territory of Austria for a period of time } \\
\text { that is not merely temporary. }\end{array}$ \\
\hline & $\begin{array}{l}\text { S apply: } \\
\text { on the hiring of foreign workers continue to apply after } \\
\text { permit is required in order to obtain gainful employ- } \\
\text { ns apply to workers on secondment. Moreover, those } \\
\text { rk permit for a period of at least one year will find it } \\
\text { equent work permits. }\end{array}$ \\
\hline & $\begin{array}{l}\text { apply: } \\
\text { it new Member States may be granted work and resi- } \\
\text { obtain full-time work in Denmark which is governed } \\
\text { greement. Applicants may not start work in Denmark } \\
\text { pranted a residence permit by the Danish Immigration } \\
\text { plies only for the specific job for which it is issued. If } \\
\text { o, he or she must apply for a new residence permit. If } \\
\text { e residence permit is withdrawn. } \\
\text { issued for no more than one year at a time. }\end{array}$ \\
\hline & $\begin{array}{l}\text { apply: } \\
\text { a transitional period applying to the free mobility of } \\
\text { Finland on } 1 \text { May } 2004 \text {. The introduction of transi- } \\
\text { d is based on the joint approach adopted by the EU } \\
\text { n spring } 2001 \text {. According to this, Finland initially ob- } \\
\text { itional period and a decision on whether or not to pro- } \\
\text { a tripartite basis before the end of the second year. }\end{array}$ \\
\hline & $\begin{array}{l}\text { r States, who are subject to French legislation on the working } \\
\text { ens (from third countries). } \\
\text { decided to apply transitional arrangements to salaried workers } \\
\text { w Member States for an initial period of no less than two years } \\
\text { te of accession (1 May 2004). } \\
\text { of this period (1 May 2006), an evaluation of the situation will } \\
\text { ut at national level to determine the impact of opening up the } \\
\text { ur market. France will then determine its exact position in ac- } \\
\text { th the Athens Treaty. }\end{array}$ \\
\hline
\end{tabular}

${ }^{36}$ The table refers to the transitional measures that the fifteen old Member States introduced for workers from the eight new Member States on 1 May 2004. It does not refer to the free movement of workers from Cyprus and Malta, which were not subject to transitional arrangements. The data were collected from the European Employment Services (EURES) 'Information on the transitional rules governing the free movement of workers from, to and between the new member states' <http://ec.europa.eu/eures/main.jsp?acro=free\&step=0 \&lang=en> accessed in January 2005. 


\section{National restrictions apply:}

For the first two years, nationals of the new Member States are subject to the transitional provisions on free movement of workers and services providers set up in the Accession Treaty. Work permits are issued in exceptional circumstances as provided for in the regulations governing exceptions to the 5 recruitment ban when examination of the labour market shows that no job seekers are available who would take precedence (eg Germans).

\section{National restrictions apply:}

Because of the initial two-year transitional period for access to the labour market, citizens of the new Member States may enter Greece for paid work provided they are issued a work permit.

Citizens of the new EU Member States who on the date of accession (1 May 2004) have been legally employed in Greece for a period of twelve months or more, without interruption, are treated as Community citizens insofar as access to employment is concerned. Citizens of the new EU Member States who are legally employed in Greece on the date of accession (1 May 2004) but have not completed a twelve-month period of continuous employment are treated as Community citizens insofar as access to employment is concerned $₫$ as soon as they have completed a twelve-month period of continuous, legal employment. Citizens of the new EU Member States entering this country for $\$$ paid employment after the date of accession and who follow the transitional arrangements will be treated as Community citizens insofar as access to employment is concerned when they have completed a twelve-month term of legal, continuous employment. Citizens of the new EU Member States employed in this country before the date of accession, whose work permit expired before 1 May 2004 and has not been renewed, will also be considered Community citizens once they have fulfilled any outstanding social security obligations, as laid down in Article 25 of Act 3 242/04.

Citizens of the new Member States who enter Greece for paid employment while the transitional arrangements apply are allowed to change their occupation from paid employment to independent economic activity, but not vice versa.

\section{No national restrictions:}

Ireland has not introduced restrictions with regard to labour market access.

Citizens of the new Member States are welcome to take up work in Ireland

on the same basis as nationals of the old Member States. In accordance with

Community law, persons seeking work are entitled to come to Ireland for this purpose. While seeking work, they are not entitled to social assistance from the Irish authorities.

\section{National restrictions apply:}

The entry of workers from the eight new Member States to the Italian labour market is subject to transitional arrangement. In 2004, in addition to the $\underset{⿶}{ \pm}$ quota already provided for in the decrees regulating the flow of workers from outside the Community, a further 20,000 workers from these eight countries were permitted to enter Italy for paid employment.

\section{National restrictions apply:}

on The law of 29 April 2004 (on changes to the amended law of 28 March 1972

concerning the entry and residence of foreigners; medical checks on foreign-

ers; the employment of foreign workers) maintains the requirement for a work permit for nationals of the new Member States during the transitional period.

Any such national who finds employment in the Grand Duchy of Luxembourg

3 must obtain a work permit. It is the employer's responsibility to request this permit from the Ministry of Labour and Employment. 


\section{National restrictions apply:}

During the first two years, a work permit is required for workers from the eight new Member States. Generally speaking, there are two procedures that may apply:

A. The full work permit procedure, including a check that the job could not be performed by a worker from the Netherlands or other old Member State.

B. A number of sectors and occupations are exempt from the regular work permit procedure. In that case, a work permit is granted to workers from the

new Member States within two weeks, without the need to check whether the job could be performed by a worker from the Netherlands or other old Member State, provided the employment contract and working conditions are legally sound.

The sectors and occupations to which procedure B applies were established to take effect on 1 May 2004, and are renewed every three months. For the first and second three-month periods, the abridged procedure applied to the following occupations and occupational groups:

- International transport: international drivers

- Inland navigation: seamen, helmsmen

- Health care sector: operating theatre (OT) assistants, radiotherapy/diagnostic laboratory attendants

- Slaughtering sector: boners, slaughtermen

National restrictions apply:

For workers from the eight new Member States, Portugal continues to apply, during the first two years, the same scheme which regulates access for workers from third countries to the Portuguese labour market. Portugal still envisages the possibility of concluding bilateral agreements with some countries who have expressed an interest in doing so. The terms of these agreements and how they will tie in with the general scheme are still to be defined. During the transitional period, citizens of the new Member States need a work permit. Every two years, the Portuguese government establishes a quota for the number of citizens of third countries allowed to exercise certain professional activities in Portugal.

National restrictions apply:

The Spanish position is based on the introduction of a two-year transition $\mathbf{g}$ period for freedom of movement of salaried employees from the eight new Member States. This initial transition two-year period will be used in the है first instance to integrate fully the workers from the eight new States who are already established in Spain, granting them full equality of treatment and applying the relevant rules on family reunification.

No national restrictions:

The Swedish parliament has decided that Sweden will not apply any special transitional arrangements in respect of the eight new Member States. This means that as of 1 May 2004, job seekers from the newly acceded Member States are able to work in Sweden under the same conditions as workers

: from the old Member States and the EEA.

Job seekers from the new Member States are treated in the same way as persons from the old Member States. This means that they are entitled to register with labour offices and to receive assistance in seeking work. The same availability requirements apply to persons who arrive in Sweden with form E303, ie job seekers who are entitled to continue to receive unemployment benefit from their country of origin ('three month job seekers') as for other job seekers. 
No transitional restrictions on the free movement of workers, with restricted access to social security benefits:

There is no restriction on the free movement of workers from the new EU Member States coming to the United Kingdom. However, a registration scheme has been introduced to monitor the impact of EU enlargement on the UK labour market, and social security legislation has been amended to restrict access to certain means-tested benefits. In addition, the amendments to the law on preventing illegal working introduced changes to the types of documents UK employers must check to avoid employing illegal workers.

Worker Registration Scheme

Job seekers from eight of the new EU Member States are required to register with the UK Home Office within one month of taking up work in the United Kingdom. (This requirement applies to workers from all of the new Member States except Malta and Cyprus, who are exempt.) There is a $£ 50$ fee for joining the Worker Registration Scheme.

Workers from the eight new Member States must remain in employment for a continuous period of 12 months to obtain the right of residence in the UK. If the period of employment is interrupted, the worker must start a new job within 30 days and re-register for this to be treated as continuous employment. The registration fee is only charged when the worker first joins the Worker Registration Scheme (WRS). There are no further charges if a worker has to re-register.

The scheme applies to workers from the eight new Member States who:

- start a new job on or after 1 May 2004;

- have been working in the UK before 1 May without authorisation,

- are working on a short-term or temporary basis;

- are students who are also working.

The following persons do not need to register on the WRS:

I - the self-employed;

- those who have worked legally in the UK for 12 months or more in their current job on 1 May 2004;

- those who have been working legally in the UK and who have stayed in the same job after 1May 2004;

- those who were given leave to enter the UK as a participant on the Seasonal Agricultural Workers Scheme (SAWS) before 1 May 2004,

- those who are providing services in the UK on behalf of an employer who is not established in the UK;

- those who are the family member (spouse, or child under the age of 21) of a Swiss or EEA national who is in the UK working;

- those who are the family member of a Swiss or EEA national who is in the UK and who are students, have retired, or are self-sufficient;

- those who are a family member of a person who is legally working in the UK.

Changes to Social Security Regulations:

The Social Security (Habitual Residence) Amendment Regulations 2004 deal with entitlement to means-tested benefits. The regulations introduce a new requirement that a claimant must be able to demonstrate a 'right to reside' in the UK. Workers from the eight new Member States who came to the UK to work after 1 May 2004 can only have a right to reside if they are working and registered under the Workers Registration Scheme or they have completed the initial 12-months period as registered workers in continuous employment.

During the initial 12-month period, the worker is entitled to Child Benefit and in-work benefits, such as tax credits. If they have a low income, they may also be entitled to Housing Benefit and Council Tax benefit.

Changes to the Law on Illegal Working:

Section 8 of the Asylum and Immigration Act 1996 requires all employers in the United Kingdom to make basic document checks on every person they intend to employ. By making these checks, employers can be sure they will not break the law by employing illegal workers.

On 1 May 2004, the Government introduced changes to the types of document that a United Kingdom employer needs to check to avoid employing illegal workers. Prospective employees are usually required to produce a national passport or a national identity card as their means of identification. 
Table 3: Free movement of workers from Bulgaria and Romania into the EU25 on 1 January 2007: an overview of transitional measures ${ }^{37}$

\begin{tabular}{|c|l|}
\hline Application of national restrictions: \\
Austria maintained a work permit requirement and restrictions on the \\
posting of workers in certain sectors.
\end{tabular}

37 The table refers to the transitional measures that the twenty-five Member States (all Member States that acceded to the Union before Bulgaria and Romania) introduced for Bulgarian and Romanian workers on 1 January 2007. The data were collected on the web pages of the European Commission: http://ec.europa.eu/employment_social/free_movement/enlargement_en.htm accessed 10 October 2007. 


\begin{tabular}{|c|c|}
\hline छ్ & $\begin{array}{l}\text { Application of national restrictions: } \\
\text { Ireland maintained a work permit requirement. }\end{array}$ \\
\hline 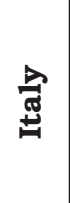 & $\begin{array}{l}\text { Application of national restrictions: } \\
\text { Italy maintained a work permit requirement. There is no work permit } \\
\text { requirement for employment in certain sectors (agriculture, hotel and } \\
\text { tourism, domestic work, care services, construction, engineering, } \\
\text { managerial and highly skilled work, seasonal work). }\end{array}$ \\
\hline 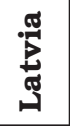 & No national restrictions \\
\hline 茞 & No national restrictions \\
\hline 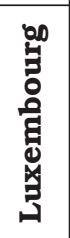 & $\begin{array}{l}\text { Application of national restrictions: } \\
\text { Luxembourg maintained a work permit requirement. Simplified procedures } \\
\text { for work have been introduced for work in agriculture, viticulture, the hotel } \\
\text { and catering sector and for people with specific qualifications for which } \\
\text { there is a need in the financial sector. }\end{array}$ \\
\hline 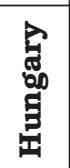 & $\begin{array}{l}\text { Application of national restrictions: } \\
\text { Hungary maintained a work permit requirement. A simplified procedure } \\
\text { applies for } 219 \text { occupations where a work permit is issued without } \\
\text { considering the job situation or without a labour market review. }\end{array}$ \\
\hline 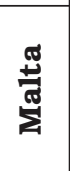 & $\begin{array}{l}\text { Application of national restrictions: } \\
\text { Malta grants work permits for positions that require qualified and/ } \\
\text { or experienced workers and for those occupations for which there is a } \\
\text { shortage of workers. }\end{array}$ \\
\hline 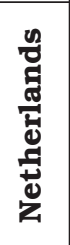 & $\begin{array}{l}\text { Application of national restrictions: } \\
\text { In the Netherlands, a work permit will be issued when there are no } \\
\text { workers available in the Netherlands or other EU Member States and } \\
\text { when the employer concerned can offer proper working conditions and } \\
\text { accommodation. Temporary exemptions may be granted for sectors in } \\
\text { which there is a labour shortage. }\end{array}$ \\
\hline 密 & $\begin{array}{l}\text { Application of national restrictions: } \\
\text { Germany maintained a work permit requirement and applies restrictions } \\
\text { on the posting of workers in certain sectors. }\end{array}$ \\
\hline 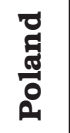 & No national restrictions \\
\hline 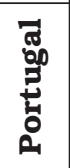 & $\begin{array}{l}\text { Application of national restrictions: } \\
\text { Portugal maintained a work permit requirement. }\end{array}$ \\
\hline
\end{tabular}




\begin{tabular}{|c|c|}
\hline$\frac{\sqrt{2}}{2}$ & No national restrictions \\
\hline 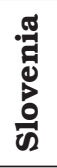 & No national restrictions \\
\hline $\begin{array}{l}\text { 晃 } \\
\text { है }\end{array}$ & $\begin{array}{l}\text { Application of national restrictions: } \\
\text { Spain maintained a work permit requirement. The issuing of a work permit } \\
\text { is directly linked to obtaining a job offer and approval of the application } \\
\text { by the employer. }\end{array}$ \\
\hline 矢 & No national restrictions \\
\hline 崃 & $\begin{array}{l}\text { Application of national restrictions: } \\
\text { In the UK, the employer must apply for a work permit (except for certain } \\
\text { categories of employment) and the worker must apply for an 'Accession } \\
\text { worker card'. Low-skilled workers are restricted to existing quota schemes } \\
\text { in the agricultural and food processing sectors. Skilled workers can work } \\
\text { if they qualify for a work permit or under the Highly Skilled Migrant } \\
\text { Programme. }\end{array}$ \\
\hline
\end{tabular}

\section{Are transitional arrangements necessary and justified?}

Why have transitional arrangements been adopted, and are they necessary? In its Information Note 'The Free Movement of Workers in the Context of Enlargement' ${ }^{38}$ and the Draft Common Position, the Commission proposed a transitional period due to concerns in relation to expected labour migration with a potential to seriously disturb the labour markets in the Member States'. Its concerns were based on considerations such as 'geographical proximity, income differentials between the old and the new Member States, high unemployment and propensity to migrate'. ${ }^{39}$ The issue remains about how necessary such measures really are, while the "what if question also arises, testing what would have happened if no transitional measures had been imposed by the old Member States. A number of studies have been made on the potential for labour migration after enlargement where the estimates of migration potential vary (see Table 4).

38 Commission (EC) (n 3).

39 Commission (EC) (n 3) 2. 
Table 4: Results of studies estimating potential migration into the EU-15 upon enlargement under conditions of free movement of workers $^{40}$

\begin{tabular}{|c|c|c|c|c|}
\hline & \multicolumn{2}{|c|}{ CEES8 $^{41}$} & \multicolumn{2}{|c|}{ CEES10 $^{42}$} \\
\hline & Stock & $\begin{array}{c}\text { Flow/year over } \\
\text { first } 10 \text { years }\end{array}$ & Stock & $\begin{array}{c}\text { Flow/year over } \\
\text { first } 10 \text { years }\end{array}$ \\
\hline $\begin{array}{l}\text { Brückner (DIW) and } \\
\text { Boeri (2000) } \\
\text { (only workers) }\end{array}$ & $\begin{array}{c}860,000 \\
\text { (after } 10 \text { years) }\end{array}$ & $\begin{array}{l}70,000 \text { declining } \\
\text { to } 30,000\end{array}$ & $\begin{array}{l}1.4 \text { million } \\
\text { (after } 10 \text { years) }\end{array}$ & $\begin{array}{c}120,000 \text { declining } \\
\text { to } 50,000\end{array}$ \\
\hline $\begin{array}{l}\text { Brückner (DIW) and } \\
\text { Boeri (2000) }{ }^{44} \\
\text { (all migrants) }\end{array}$ & $\begin{array}{l}1.8 \text { million } \\
\text { (after } 10 \text { years) }\end{array}$ & $\begin{array}{l}200,000 \text { declining } \\
\text { to } 85,000\end{array}$ & $\begin{array}{c}2.9 \text { million } \\
\text { (after } 10 \text { years) }\end{array}$ & $\begin{array}{l}335,000 \text { declining } \\
\text { to } 145,000\end{array}$ \\
\hline $\begin{array}{l}\text { Sinn (ifo) et al } \\
(2001)^{45}\end{array}$ & $\begin{array}{c}2.7 \text { million } \\
\text { (after } 15 \text { years) }\end{array}$ & $\begin{array}{l}240,000 \text { declining } \\
\text { to } 125,000\end{array}$ & $\begin{array}{c}4.2 \text { million } \\
\text { (after } 15 \text { years) }\end{array}$ & $\begin{array}{c}380,000 \text { declining } \\
\text { to } 200,000\end{array}$ \\
\hline $\begin{array}{l}\text { Walterskirchen (WIFO) } \\
\text { and Dietz (1998) } \\
\text { (excl. commuters) }\end{array}$ & & $\begin{array}{l}160,000 \text { declining } \\
\text { to } 110,000\end{array}$ & & \\
\hline $\begin{array}{l}\text { Bauer and Zimmer- } \\
\text { man }^{47} \text { (IZA) (1999) }\end{array}$ & $\begin{array}{c}2.5 \text { million } \\
\text { (after } 15 \text { years) }\end{array}$ & & & 200,000 \\
\hline $\begin{array}{l}\text { Fassmann and } \\
\text { Hintermann }^{48}(1997)\end{array}$ & $\begin{array}{l}720,000 \text { long- } \\
\text { term migration }\end{array}$ & & & \\
\hline $\begin{array}{l}\text { Hille and Straubhaar }{ }^{49} \\
(2000)\end{array}$ & & & & $\begin{array}{c}270,000 \text { to } \\
790,000\end{array}$ \\
\hline $\begin{array}{l}\text { Salt and others }{ }^{50} \\
\text { (1999) }\end{array}$ & $\begin{array}{c}2.25 \text { million } \\
\text { ( } 3 \% \text { of } \\
\text { population) } \\
\text { (after } 15 \text { years) }\end{array}$ & 140,000 & & \\
\hline
\end{tabular}

40 Commission (EC) (n 3) Table 5

41 Eight Central and Eastern European states: the Czech Republic, Hungary, Poland, Slovakia, Slovenia, Estonia, Latvia, Lithuania.

42 Ten Central and Eastern European states: the Czech Republic, Hungary, Poland, Slovakia, Slovenia, Estonia, Latvia, Lithuania, Bulgaria, Romania.

${ }^{43} \mathrm{H}$ Brückner and T Boeri, The Impact of Eastern Enlargement on Employment and Labour Markets in the EU Member States (DIW \& IGIER 2000).

${ }^{44}$ Brückner and Boeri (n 43)

${ }^{45}$ H-W Sinn, 'EU-Erweiterung und Arbeitskräftemigration. Wege zu einer schrittweisen Annäherung der Arbeitsmarktes' (2001) 2 ifo Beiträge zur Wirtschaftsforschung. Excluding Bulgaria, Slovenia and the Baltic States.

${ }^{46}$ E Walterkirchen and R Dietz, 'Auswirkungen der EU-Ost-Erweiterung auf den Österreichischen Arbeitsmarkt' (1998) Österreichisches Institut für Wirtschaftsforschung.

${ }_{47} \mathrm{~T}$ Bauer and KF Zimmermann, 'Assessment of Possible Migration Pressure and its Labour Market Impact Following EU Enlargement to Central and Eastern Europe' Study for the UK Department for Education and Employment (IZA Bonn \& CEPR London 1999). Excluding Slovakia and Baltic States.

${ }^{48}$ H Fassmann and C Hintermann, 'Migrationspotential Ostmitteleuropa - Struktur und Motivation Potentieller Migranten aus Polen, der Slowakei, Tschechien und Ungarn' (1997) Österreichischen Akademie der Wissenschaften. Excluding Slovenia and Baltic States.

${ }^{49} \mathrm{H}$ Hille and T Straubhaar, 'The Impact of EU Enlargement on Migration Movements and Economic Integration: Results of Recent Studies' OECD Discussion Paper (2001) 79-101.

$50 \mathrm{~J}$ Salt and others, 'Assessment of Possible Migration Pressure and its Labour Market Impact Following EU Enlargement to Central and Eastern Europe: Part 1' (Research Report No 138) (1999) Department of Education and Employment, London. Excluding the Baltic States. 
A study produced for the European Commission in 2000 by the European Integration Consortium ${ }^{51}$ examined the impact of enlargement on the EU labour market in the case of the accession of 10 Central and Eastern European states (including Bulgaria and Romania) in 2002 and the absence of any migration restrictions after accession. The study found that the opening of borders for workers immediately upon accession would have only a minor impact on the EU labour market and a rather small impact on employment and wages in the Union, even in the two most affected countries, Austria and Germany. Nevertheless, in some branches and regions blue-collar workers might be negatively affected if immigration increased by several percentage points in a few years. ${ }^{52}$ The study estimated an initial annual immigration rate of some 335,000 residents from ten Central and Eastern European states (CEES10), or 200,000 residents from eight Central and Eastern European states (CEES8 - Bulgaria and Romania excluded), which would have declined by the end of the decade to fewer than 150,000 (CEES10), or 85,000 (CEES8) immigrants annually. The study expected some 2.9 million (CEES10), or 1.8 million (CEES8) immigrants by the end of the first decade. ${ }^{53}$ Based on the results of their research, the authors of the study advised against the introduction of transitional arrangements for free movement of labour and, instead, proposed a system of quotas for a period of limited duration. ${ }^{54}$ Despite this and similar research results, the old Member States decided to play (politically) safe and insisted on transitional arrangements.

In 2003 the European Integration Consortium updated its study, produced in 2000, of the potential for migration from the ten Central and Eastern European states into the EU- $15 .{ }^{55}$ Among its other objectives, the updated study aimed at analysing the implications of migration restrictions during the transitional periods for the short-run and long-run migration potential. At the time of completing the update, it was already clear that Bulgaria and Romania would not join the Union in 2004 and that the old Member States would be allowed a transitional period which could postpone the introduction of free movement for up to seven years. Thus, the updated study simulated the impact of transitional periods of two, five and seven years in Germany, rightly presuming that the accession of eight Central and Eastern European states would take place in 2004. The simulation was based on the assumption that a restrictive

\footnotetext{
51 Brückner and Boeri (n 43).

52 Brückner and Boeri (n 43) 136.

53 Brückner and Boeri (n 43) 126.

54 Brückner and Boeri (n 43) 131.

55 P Alvarez-Plata, H Brücker and B Silverstovs, 'Potential Migration from Central and Eastern Europe into the EU15 - An Update' (Report for the European Commission) (2003) DIW Berlin.
} 
policy of zero net migration was pursued. ${ }^{56}$ The results of the research showed that postponing free movement of labour would neither reduce net migration flows in the initial years after lifting the restrictions nor would it affect the long-run stocks of foreign population (see Figure 1). ${ }^{57}$ The study also showed the implications of the most restrictive scenario for Germany - transitional arrangements until 2011 for 8 Central and Eastern European states that acceded in 2004, and until 2014 for Bulgaria and Romania (see Figure 2). In this case, the number of immigrants would peak at approximately 195,000 in 2015, one year after restrictions had been lifted for Bulgaria and Romania. This is 50,000 migrants fewer than if free movement had been introduced for 10 Central and Eastern European states (including Bulgaria and Romania) in 2004. These results show that, even though transitional periods postpone migration, they have only a marginal impact on the size of the inflows and the long-run stock of migrants. ${ }^{58}$ The results of the research thus once again clearly question the legitimacy of transitional periods and support the view that the issue of free movement of labour in the enlarged Union is a political rather than an economic or social question.

Figure 1: Simulation of the impact of transitional periods on migration from 8 Central and Eastern European states ${ }^{59}$

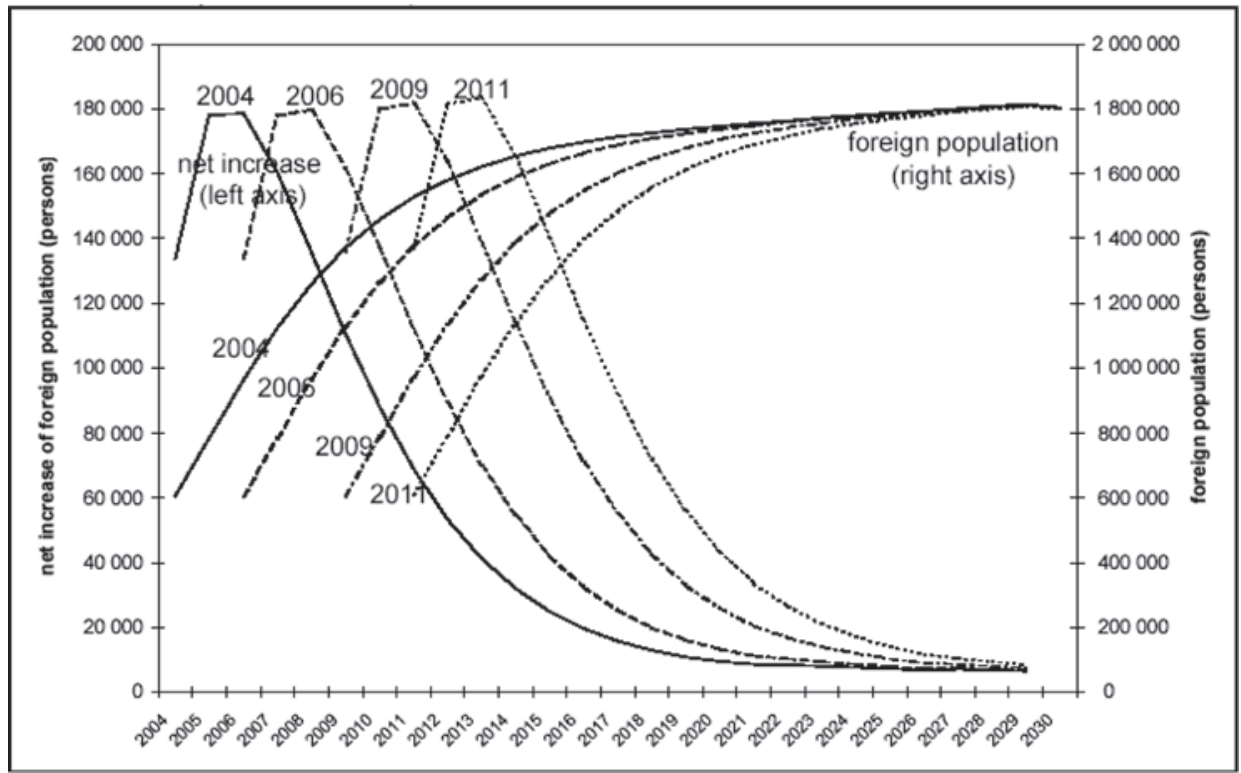

56 Zero net migration means that the sum of all movements (persons entering and departing the country) is zero.

57 Alvarez-Plata (n 55) 41.

58 Alvarez-Plata (n 55) 42.

59 Alvarez-Plata (n 55) 41. 
Figure 2: Simulation of the impact of the utilisation of the maximal length of transitional periods on migration from 10 Central and Eastern European states ${ }^{60}$

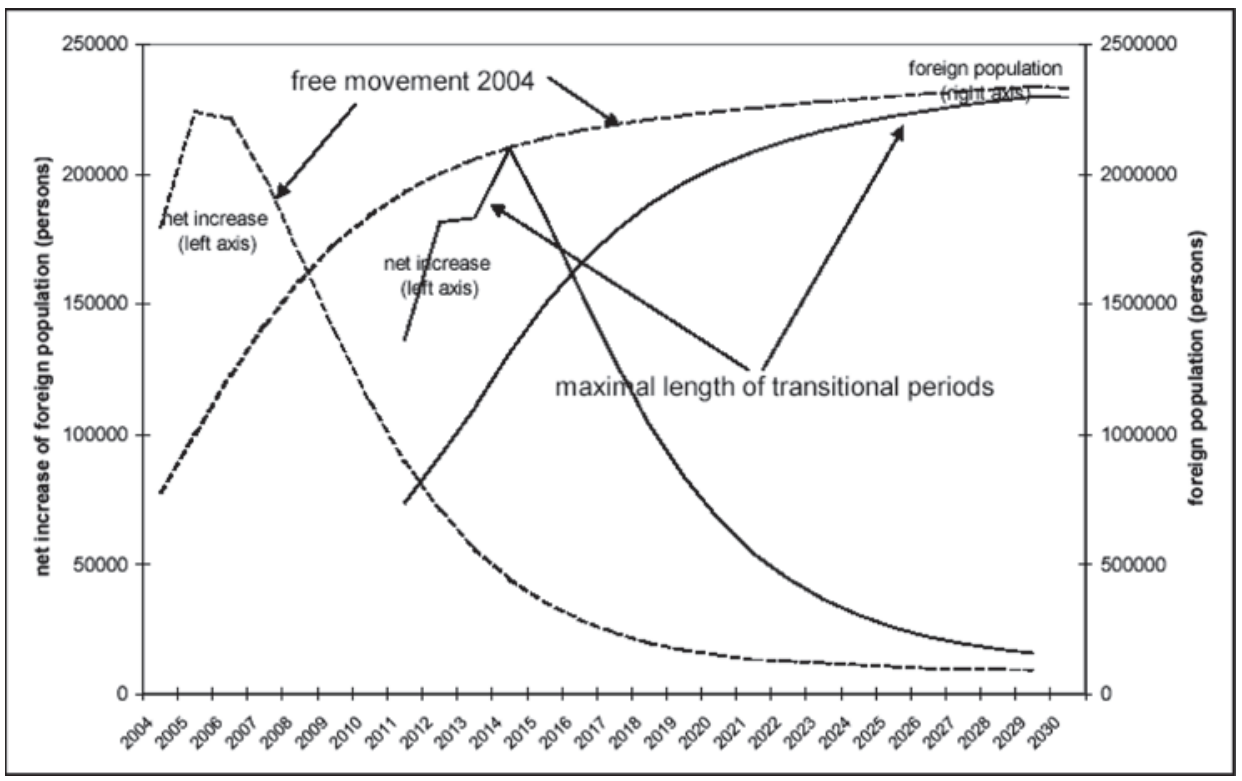

Additionally, the need for transitional restrictions is even more questionable in the light of the previous Spanish and Portuguese accession. In the accession arrangements for Spain and Portugal, free movement of workers was subject to a seven-year transitional period, in which time Member States were allowed to maintain their national measures or those resulting from bilateral agreements. During the transitional period, about 1,000 Spanish and 6,000 Portuguese workers received work permits in other Member States every year (including renewals of existing ones). The fear of any major migration pressure did not materialise. The trend did not change with the expiry of the transitional periods, and migration flows still kept relatively small. Migration of Spanish nationals kept stable while the Portuguese figure continued to increase until an annual level of 30,000 residents was reached. Taking into account reverse migration, by 1995 the number of Spanish and Portuguese residents in other Member States actually declined by $0.3 \%$ and $1.1 \%$ respectively. ${ }^{61}$ In view of the previous transitional arrangements for Spain and Portugal, which were less flexible (since the earliest shortening of transitional restrictions could take place only five years after accession), the transitional arrangements for the eight Central and Eastern European states that joined the

60 Alvarez-Plata (n 55) 43.

61 Commission (EC) (n 3) 16. 
Union in 2004 and for Bulgaria and Romania which joined in 2007 are more liberal and flexible. However, one wonders whether a better solution could have been found, such as immigration quotas, presented as one of the options in the Commission's Information Note and in Brückner and Boeri. ${ }^{62}$

The most recent indicators of the initial two-year transitional arrangements also question the necessity of imposing transitional restrictions in the field of free movement of workers in the European Union. In its Report on the Functioning of the Transitional Arrangements set out in the 2003 Accession Treaty (period 1 May 2004 - 30 April 2006), ${ }^{63}$ based on statistical analysis, the European Commission concluded that the mobility flows from the ten new Member States into the EU-15 is very limited (see Table 6) and, as such, they cannot affect the EU labour market in general. Furthermore, mobility flows from the old to the new Member States and between the ten new Member States is generally negligible. The Commission also stated that the percentage of nationals from the new Member States in the resident population of each EU-15 Member State was relatively stable before and after enlargement (see Tables 5 and 6). Increases were recorded only in the UK, Ireland and Austria (where they stabilised in 2005). The Commission further ascertained that there was no evidence to show a direct link between mobility flows from the ten new Member States and the transitional arrangements. For example, the comparison between the percentage of nationals from new Member States resident in the UK and Sweden from 2003 to 2005 (as the states which had not introduced transitional restrictions) and those resident in other old Member States (which had maintained transitional restrictions) shows that mobility flows in the UK and Sweden were similar or lower than the mobility flows in the other old Member States (see Tables 5 and 6). The Commission also noted that the employment rate of nationals in the ten new Member States was similar to that of the country nationals in the old EU-15 Member States, or even higher in Ireland, Spain and the UK (see Table 7). Most importantly, in its Report, the Commission concluded that migration flows following enlargement have had positive effects on the economies of the old EU-15 Member States. They contributed to the overall labour market performance, to sustained economic growth and to better public finances. In several old EU-15 Member States, the employment rate has increased since enlargement. The Commission sees the reasons for such an increase in the positive effect enlargement has had on formalising the underground economy constituted by previously undocumented workers from the ten new Member States, in the change

62 Brückner and Boeri (n 43), 131, 136.

63 Report on the Functioning of the Transitional Arrangements set out in the 2003 Accession Treaty (period 1 May 2004 - 30 April 2006), COM(2006) 48 final, 8 February 2006. 
in employers' attitudes, and in better information and regulation (see Table 7). Finally, the Commission concluded that nationals from the ten new Member States have a complementary role, since there is no evidence of the crowding out of national workers as a result of the inflow of workers from the new Member States.

Table 5: Resident working age population - 2003-2005 - cell percentages ${ }^{64}$

\begin{tabular}{|l|r|r|r|r|r|r|}
\hline \multirow{2}{*}{ County of destination } & \multicolumn{7}{|c|}{ Nationality } \\
\cline { 2 - 8 } & \multicolumn{3}{|c|}{ EU15 } & \multicolumn{3}{|c|}{ EU10 } \\
\cline { 2 - 8 } & $\mathbf{2 0 0 3}$ & $\mathbf{2 0 0 4}$ & $\mathbf{2 0 0 5}$ & $\mathbf{2 0 0 3}$ & $\mathbf{2 0 0 4}$ & $\mathbf{2 0 0 5}$ \\
\hline Belgium & 5.4 & 5.8 & 5.8 & 0.2 & 0.2 & 0.2 \\
\hline Genmark & 1 & 1.1 & 1.1 & $:$ & $:$ & $:$ \\
\hline Greece & 2.7 & 2.6 & 2.8 & $:$ & $:$ & 0.7 \\
\hline Spain & 0.2 & 0.4 & 0.3 & 0.3 & 0.4 & 0.4 \\
\hline France & 1.1 & 1.2 & 1.2 & 0.2 & 0.2 & 0.2 \\
\hline Ireland & 1.9 & 2.1 & 1.9 & 0.1 & 0.1 & 0.1 \\
\hline Luxembourg & 3.4 & 3.3 & 3 & & $:$ & 2 \\
\hline Netherlands & 37.2 & 37.6 & 37.6 & 0.3 & 0.3 & 0.3 \\
\hline Austria & 1.5 & 1.5 & 1.4 & 0.1 & 0.1 & 0.1 \\
\hline Portugal & 1.7 & 1.8 & 1.9 & 0.7 & 0.8 & 1.4 \\
\hline Finland & 0.3 & 0.4 & 0.4 & & & $:$ \\
\hline Sweden & 0.3 & 0.3 & 0.4 & 0.3 & 0.3 & 0.3 \\
\hline UK & 2.2 & 2.2 & 2.3 & 0.2 & 0.2 & 0.2 \\
\hline EU15 & 1.8 & 1.8 & 1.7 & 0.2 & 0.3 & 0.4 \\
\hline EU10 & 2 & 2.1 & 2.1 & 0.2 & 0.2 & 0.4 \\
\hline EU25 & & 0.2 & 0.2 & $:$ & 0.1 & 0.2 \\
\hline
\end{tabular}

Source: Eurostat, LFS, 2003 - 2005 Q1, Ireland 2005 Q2.

Notes: The colon (:) represents data not available or not reliable due to the small sample size.

Italy is excluded, since it does not disaggregate by nationality.

EU15 and EU25 aggregates without Italy, EU15 and EU25 aggregates without Germany and Ireland in 2003-2004 for EU10 nationals. EU10 aggregate without Poland.

64 Commission (EC), 'Report on the Functioning of the Transitional Arrangements set out in the 2003 Accession Treaty (period 1 May 2004 - 30 April 2006)' COM(2006) 48 final, 8 February 2006, 9. 
Table 6: Resident working age population by nationality - 2005 - row percentages $^{65}$

\begin{tabular}{|l|cccc|}
\hline \multirow{2}{*}{ County of destination } & \multicolumn{4}{|c|}{ Nationality } \\
\cline { 2 - 5 } Belgium & National & EU15 & EU10 & Non-EU \\
Denmark & 91.3 & 5.8 & 0.2 & 2.8 \\
Germany & 96.4 & 1.1 & $:$ & 2.4 \\
\cline { 2 - 5 } Greece & 89.5 & 2.8 & 0.7 & 7 \\
Fpain & 94 & 0.3 & 0.4 & 5.3 \\
Ireland & 90.5 & 1.2 & 0.2 & 8.1 \\
Luxembourg & 94.4 & 1.9 & 0.1 & 3.6 \\
Netherlands & 92.3 & 3 & 2 & 2.8 \\
Austria & 57.9 & 37.6 & 0.3 & 4.2 \\
Portugal & 95.7 & 1.4 & 0.1 & 2.8 \\
Finland & 89.2 & 1.9 & 1.4 & 7.5 \\
Sweden & 97 & 0.4 & $:$ & 2.6 \\
UK & 98.3 & 0.4 & 0.3 & 1 \\
\hline EU15 & 94.8 & 2.3 & 0.2 & 2.7 \\
EU10 & 93.8 & 1.7 & 0.4 & 4.1 \\
\hline EU25 & 92.4 & 2.1 & 0.4 & 5.1 \\
\hline
\end{tabular}

Source: Eurostat, LFS, 2005 Q1, Ireland 2005Q2.

Notes: The colon (:) represents data not available or not reliable due to the small sample size. Italy is excluded, since it does not disaggregate by nationality. EU-15 and EU-25 aggregates without Italy. EU-10 aggregate without Poland.

Table 7: Employment rates by nationality - 2005 - cell percentages ${ }^{66}$

\begin{tabular}{|c|c|c|c|c|c|}
\hline \multirow{3}{*}{$\begin{array}{l}\text { County of } \\
\text { destination }\end{array}$} & \multirow{3}{*}{$\begin{array}{l}2004 \\
\text { EU10 }\end{array}$} & \multicolumn{4}{|c|}{2005} \\
\hline & & \multicolumn{4}{|c|}{ Nationality } \\
\hline & & National & EU15 & EU10 & Non-EU \\
\hline Belgium & 64 & 62 & 60 & 55 & 35 \\
\hline Germany & : & 67 & 68 & 51 & 48 \\
\hline Greece & 47 & 60 & 53 & 47 & 71 \\
\hline Spain & 68 & 62 & 64 & 78 & 71 \\
\hline France & 61 & 64 & 69 & 62 & 44 \\
\hline Ireland & : & 67 & 69 & 85 & 57 \\
\hline Netherlands & 63 & 74 & 76 & 64 & 41 \\
\hline Austria & 58 & 69 & 72 & 66 & 60 \\
\hline Finland & 67 & 69 & 67 & 55 & 45 \\
\hline Sweden & 62 & 74 & 73 & 62 & 45 \\
\hline UK & 72 & 72 & 69 & 75 & 58 \\
\hline EU15 & 59 & 67 & 68 & 62 & 55 \\
\hline EU10 & : & 57 & 59 & 68 & 63 \\
\hline EU25 & 59 & 65 & 67 & 62 & 55 \\
\hline
\end{tabular}

Source: Eurostat, LFS, 2004 - 2005 Q2.

Notes: The colon (:) represents data not available or not reliable due to the small sample size. Italy is excluded, since it does not disaggregate by nationality.

Denmark, Luxembourg and Portugal are excluded due to the small sample size.

EU15 and EU10 aggregates in 2004 based on Germany and Ireland 2005Q2 data.

65 Commission (EC) (n 64) 17.

66 Commission (EC) (n 64) 11. 
The above conclusions reached in the Commission's Report are compatible with the existing studies in this field. ${ }^{67}$ The studies which assess the impact of migration on the UK, as one of the three old Member States which opened their labour markets to nationals from the eight new Member States in 2004, show that the economic impact of migration from the new Member States has been modest but broadly positive. ${ }^{68}$ Approximately 500,000 migrants from the eight new Member States had come to work in the UK between May 2004 and late 2006, but it appears that a significant proportion of these workers have returned to their county of origin. ${ }^{69}$ The studies suggest that immigration reduced inflationary pressures and the natural rate of unemployment in the UK, and that the lower the GDP per capita is in each of the eight new Member States, the higher the propensity to migrate to the UK. ${ }^{70}$ Furthermore, the studies indicate that the future immigration flows from the new to the old Member States will decline as the convergence of incomes in the old and the new Member States proceeds, and that the cumulative stock of migrants is expected to reach $1 \%$ of the EU- 15 population in the decade following accession. ${ }^{71}$ The majority of migrants is expected to come from Romania, Poland and Bulgaria, and the main receiving countries are predicted to be Germany and Austria. ${ }^{72}$

On the other hand, while the old Member States have so far managed to absorb workers from the new Member States without major negative effects, the movement of the labour force from the new to the old Member States has had significant impacts on the countries of the workers' origin. The fear of the new Member States of a 'brain drain' has partly turned out to be justified. Given the fact that the migrants are mostly young and highly qualified, the 'brain drain' at the same time stands for

\footnotetext{
67 For a detailed analysis see for example: A Zaiceva, 'Reconciling the Estimates of Potential Migration into the Enlarged European Union' (December 2006) IZA Discussion Paper No 2519; T Boeri,'New Citizens, Old Borders' (2004) Finance and Development 36-37; DG Blanchflower, J Saleheen, C Shadforth, 'The Impact of the Recent Migration from Eastern Europe on the UK Economy' (2007) IZA Discussion Paper No 2615; N Gilpin and others, 'The Impact of Free Movement of Workers from Central and Eastern Europe on the UK Labour Market' (2006) Working Paper No 29 Department for Work and Pensions; D Iakova, 'The Macroeconomic Effects of Migration from the New European Union Member States to the United Kingdom' (2007) IMF Working Paper WP/07/61; R Barrell, J FitzGerald, R Riley, 'EU Enlargement and Migration: Assessing the Macroeconomic Impacts' (2007) Discussion Paper No 292 National Institute of Economic and Social Research (NIESR); R Barrell, C Guillemineau, I Liadze, 'Migration in Europe' (2007) National Institute of Economic and Social Research (NIESR).

${ }^{68}$ Gilpin (n 67); Iakova (n 67).

69 Blanchflower (n 67).

70 Blanchflower (n 67) executive summary, para C.

71 Zaiceva (n 67) 1.

72 Zaiceva (n 67) 16.
} 
a 'youth drain', which poses an additional problem for the countries of origin in the light of the overall trend of population aging in Europe. Studies indicate that 3-5\% of young nationals from the new Member States who have completed tertiary level education tend to leave their home countries for better wage prospects. ${ }^{73}$ However, since such persons give preference to temporary migration, the 'brain drain' might not be the best term in this case. Although one cannot talk about a massive 'brain drain', studies suggest that an increased outflow of highly-qualified labour, particularly from the health sector, can be observed in some regions. Based on the data of the Polish Chamber of Physicians and Dentists, by June 2006 almost 5\% of health care professionals had applied for a certificate to work abroad. ${ }^{74}$

\section{Conclusion}

The above indicators from the studies made in 2006 and 2007 showing the modest but broadly positive economic impact of labour migration from the new to the old Member States confirm the results of the studies made before the 2004 enlargement. They also affirm that the opening of the borders between the new and the old Member States has mostly had positive impacts by increasing productivity, reducing unemployment and improving attitudes towards the European Union. This view is even more justified if it is considered that most EU citizens nowadays associate the Union with free movement for the purpose of work, study and travel, ${ }^{75}$ so that even a temporary removal of that right represents a blow to one of the values most frequently identified with the European Union. For this reason, we can wonder whether a better solution could have been found (such as immigration quotas, given as one of the options in the Commission's Information Note and in Brückner and Boeri), which would have been politically fairer and psychologically wiser in confronting arguments about the divide between 'first class' and 'second class EU membership'. The results of these studies, showing that the fears of opening the labour markets to nationals from the new Member States were mostly unfounded and are not comparable to the significant economic and social benefits of free movement of labour in the Union, should not be underestimated in

\footnotetext{
${ }^{73}$ J Traser, M Byrska, B Napieralski, 'Who's Afraid of EU Enlargement?' (revised version 2005) Report on the Free Movement of Workers in EU-25, European Citizen Action Service 12.

74 World Bank EU8 Quarterly Economic Report, Part II Special Topic 'Labour Migration from the New EU Member States' (2006) 23.

75 See the results of Eurobarometer for 2006 where 50\% of those asked what the European Union means for them personally associated the Union with the freedom to travel, study and work anywhere in the European Union (Eurobarometer 65 (2007)) $73<\mathrm{http}$ ///ec.europa. eu/public_opinion/archives/eb/eb65/eb65_en.pdf> accessed 10 October 2007.
} 
future EU enlargements. The next country expected to join the Union is Croatia, which has started accession negotiations. At the time of writing this text, it is still unknown whether transitional arrangements for the movement of Croatian workers into the EU will be imposed. ${ }^{76}$

76 For the Croatian perspective of the cost and benefits of migrations, see the study made for Croatian Government: S Švaljek (ed), 'Pristupanje Europskoj uniji: očekivani ekonomski učinci (Accession to the European Union: Expected Economic Impacts) Ekonomski institut (2007) 52-62.

Generally on migration flows and projections in Croatia see: M Grizelj and A Akrap, 'Projekcije stanovništva Republike Hrvatske 2004-2051' (Projections of the Croatian Population 2004-2051) (2006) Državni zavod za statistiku 15-16. 